\title{
Erratum: Optimization and Lead Selection of Benzothiazole Amide Analogs Toward a Novel Antimycobacterial Agent
}

\section{OPEN ACCESS}

Approved by:

Frontiers Editorial Office,

Frontiers Media SA, Switzerland

${ }^{*}$ Correspondence:

Frontiers Production Office

production.office@frontiersin.org

Specialty section: This article was submitted to Antimicrobials, Resistance and

Chemotherapy

a section of the journa

Frontiers in Microbiology

Received: 19 September 2019 Accepted: 20 September 2019 Published: 04 October 2019

Citation: Frontiers Production Office (2019) Erratum: Optimization and Lead Selection of Benzothiazole Amide Analogs Toward a Novel Antimycobacterial Agent.

Front. Microbiol. 10:2298. doi: 10.3389/fmicb.2019.02298

\section{Frontiers Production Office*}

Frontiers Media SA, Lausanne, Switzerland

Keywords: NTM, tuberculosis, antibacterial therapeutics, benzothiazole amide, MmpL3, efficacy, tolerability, aerosol

\section{An Erratum on}

Optimization and Lead Selection of Benzothiazole Amide Analogs Toward a Novel Antimycobacterial Agent

by De Groote, M. A., Jarvis, T. C., Wong, C., Graham, J., Hoang, T., Young, C. L., et al. (2018). Front. Microbiol. 9:2231. doi: 10.3389/fmicb.2018.02231

Due to a typesetting error, the author order was changed during the production of the article. The correct order is: Mary A. De Groote, Thale C. Jarvis, Christina Wong, James Graham, Teresa Hoang, Casey L. Young, Wendy Ribble, Joshua Day, Wei Li, Mary Jackson, Mercedes Gonzalez-Juarrero, Xicheng Sun and Urs A. Ochsner.

The publisher apologizes for this error. The original article has been updated.

Copyright $(2019$ Frontiers Production Office. This is an open-access article distributed under the terms of the Creative Commons Attribution License (CC BY). The use, distribution or reproduction in other forums is permitted, provided the original author $(s)$ and the copyright owner(s) are credited and that the original publication in this journal is cited, in accordance with accepted academic practice. No use, distribution or reproduction is permitted which does not comply with these terms. 